\title{
Faktor yang Mempengaruhi Akuntabilitas Laporan Keuangan Daerah dengan Kualitas Informasi sebagai Variabel Mediasi
}

\author{
I Wayan Aditya Paramarta ${ }^{1}$ \\ Fakultas Ekonomi dan Bisnis \\ Universitas Udayana, Indonesia
}

\author{
Dodik Ariyanto ${ }^{2}$ \\ Fakultas Ekonomi dan Bisnis \\ Universitas Udayana, Indonesia
}

\begin{abstract}
Surel : paramartaditya@gmail.com
ABSTRAK

Penelitian bertujuan untuk menganalisis faktor yang memperngaruhi akuntabilitas laporan keuangan daerah. Populasi dalam penelitian ini adalah kepala dan staf sub bidang akuntansi di pusat pemerintahan Kabupaten Badung. Teknik penentuan sampel dalam penelitian ini adalah dengan menggunakan metode non probabilty sampling dengan teknik sampling jenuh. Sampel penelitian 29 Organisasi Perangkat Daerah Kabupaten Badung. Teknik analisis dalam penelitian ini menggunakan Teknik analisis jalur. Hasil penelitian yaitu sistem pengendalian internal berpengaruh positif dan signifikan terhadap akuntabilitas keuangan daerah dan kualitas informasi. Kompetensi sumber daya manusia berpengaruh positif dan signifikan terhadap akuntabilitas keuangan daerah dan kualitas informasi. Kualitas informasi berpengaruh positif dan signifikan terhadap akuntabilitas keuangan daerah. Kualitas informasi mampu memediasi pengaruh sistem pengendalian internal dan kompetensi sumber daya terhadap akuntabilitas keuangan daerah.
\end{abstract}

Kata Kunci: Akuntabilitas; Kualitas Informasi.

\section{Factors Affecting Accountability of Regional Financial Statements with Information Quality as Mediation Variables}

\begin{abstract}
The research aims to analyze the factors that influence the accountability of local financial statements. The population in this study is the head and staff of the sub-division of accounting or in the central government of Badung Regency. The sampling technique in this research is to use the non probabilty sampling method with saturated sampling technique. The research sample is 29 Regional Organization of Badung Regency. The analysis technique in this study uses the path analysis technique. The results of the study are that the internal control system has a positive and significant effect on regional financial accountability and information quality. Human resource competence has a positive and significant effect on regional financial accountability and information quality. The quality of information has a positive and significant effect on regional financial accountability. Information quality is able to mediate the influence of internal control systems and resource competencies on regional financial accountability.
\end{abstract}

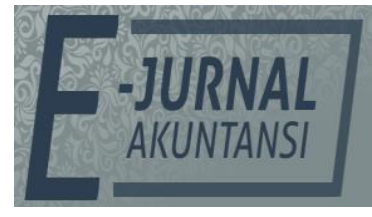

e-ISSN 2302-8556

Vol. 31 No. 5

Denpasar, Mei 2021

Hal. 1097-1109

DOI:

10.24843/EJA.2021.v31.i05.p03

PENGUTIPAN:

Paramarta, I .W.A., \& Ariyanto, D. (2021). Faktor

yang Mempengaruhi

Akuntabilitas Laporan Keuangan Daerah dengan Kualitas Informasi sebagai Variabel Mediasi. E-Jurnal Akuntansi, 31(5), 1097-1109

RIWAYAT ARTIKEL:

Artikel Masuk: 23 Februari 2020 Artikel Diterima: 19 Februari 2021

Keywords: Accountability; Information Quality.

Artikel dapat diakses : https://ojs.unud.ac.id/index.php/Akuntansi/index 


\section{PENDAHULUAN}

Akuntabilitas keuangan merupakan pertanggungjawaban mengenai integritas keuangan, pengungkapan, dan ketaatan terhadap peraturan perundangundangan IAI (2015). Sasaran pertanggung jawaban ini adalah laporan keuangan dan peraturan perundang-undangan yang berlaku mencakup penerimaan, penyimpanan, dan pengeluaran uang oleh instansi pemerintah IAI (2015). Pemerintah diminta untuk melaporkan hasil dari program yang telah dilaksanakan sehingga masyarakat dapat menilai kinerja pemerintah dari segi ekonomis, efisien dan efektif.

Meningkatnya tuntutan masyarakat terhadap penyelenggaraan pemerintahan yang baik, telah mendorong pemerintahan pusat dan pemerintahan daerah untuk menerapkan akuntabilitas publik. Akuntabilitas publik dapat diartikan sebagai bentuk kewajiban mempertanggungjawabkan keberhasilan atau kegagalan pelaksanaan misi organisasi dalam mencapai tujuan dan sasaran yang telah ditetapkan sebelumnya melalui suatu media pertanggungjawaban yang dilaksanakan secara periodik.

Informasi yang bermanfaat bagi para pemakai adalah informasi yang mempunyai nilai. Informasi akan bermanfaat jika informasi tersebut dapat mendukung pengambilan keputusan dan andal. Oleh karena itu, pemerintah wajib memperhatikan informasi yang disajikan dalam laporan keuangan untuk keperluan perencanaan, pengendalian dan pengambilan keputusan. Kebermanfaatan merupakan suatu karakteristik yang hanya dapat ditentukan secara kualitatif dalam hubungannya dengan keputusan, pemakai dan keyakinan pemakai terhadap informasi. Oleh karena itu, kriteria ini secara umum disebut dengan karakteristik kualitatif atau kualitas informasi. Draft Kerangka Konseptual Pelaporan Keuangan Tahun 2019 menyatakan adapun karakteristik kualitatif dai informasi keuangan yang berguna memiliki dua elemen, yaitu pertama karakteristik kualitatif fundamental yang terdiri atas (1) Relevansi, (2) Materialitas, (3) Representasi tepat, elemen yang kedua yaitu karakteristik kualitatif peningkat yang terdiri atas (1) keterbandingan, (2) keterverifikasian, (3) ketepatwaktuan, (4) keterpahaman.

Kabupaten Badung merupakan kabupaten yang memiliki APBD terbesar di Bali sehingga laporan keuangan pemerintah Kabupaten Badung menjadi sorotan masyarakat. Laporan keuangan pemda Badung digunakan sebagai salah satu akuntabilitas dan pertanggungjawaban kepada masyarakat dan telah diaudit oleh Badan Pemeriksa Keuangan (BPK). Berikut disajikan opini BPK terhadap laporan keuangan Kabupaten Badung.

Tabel 1. Opini BPK terhadap laporan keuangan Pemerintah Kabupaten Badung

\begin{tabular}{ll}
\hline Tahun & Opini \\
\hline 2008 & Tidak Memberikan Pendapat \\
2013 & Tidak Wajar \\
2014 & Wajar Tanpa Pengecualian \\
2015 & Wajar Tanpa Pengecualian \\
2016 & Wajar Tanpa Pengecualian \\
2017 & Wajar Tanpa Pengecualian \\
\hline
\end{tabular}

Sumber: Data Penelitian, 2019 
Hasil pemeriksaan BPK terhadap laporan keuangan Kabupaten Badung selama tiga tahun terakhir mendapatkan opini tertinggi yaitu Wajar Tanpa Pengecualian. Meskipun opini yang diberikan BPK tersebut baik pada Pemerintah Kabupaten Badung namun masih terdapat beberapa temuan pemeriksaan yaitu beberapa kelemahan dalam sistem pengendalian intern yang tentunya akan mempengaruhi keterandalan dan kualitas laporan keuangan.

Hal pertama yang mempengaruhi kualitas laporan keuangan pemerintah adalah kualitas sumber daya manusia. Proses untuk menghasilkan informasi yang berharga (reliabilitas), di sini melibatkan dua elemen utama informasi yang dihasilkan dan sumber daya yang memproduksinya. Sumber daya manusia sebagai pengguna sistem dituntut untuk memiliki tingkat keahlian akuntansi yang memadai atau setidaknya memiliki kemauan untuk terus belajar dan mengasah keterampilan dalam akuntansi (Wahyono, 2004).

Hal kedua yang dapat mempengaruhi keandalan dan ketepatan waktu pelaporan keuangan pemerintah adalah pemanfaatan teknologi informasi. Seperti kita ketahui bahwa total volume Anggaran Negara / Daerah (APBN / APBD) dari tahun ke tahun menunjukkan peningkatan yang luar biasa. Dari sisi akuntansi itu menunjukkan bahwa volume transaksi keuangan pemerintah juga menunjukkan kuantitas yang semakin besar dan kualitas yang semakin kompleks dan kompleks. Peningkatan volume transaksi yang lebih besar dan lebih kompleks tentu harus diikuti oleh kemampuan manajemen keuangan pemerintah yang ditingkatkan. Untuk itu, Pemerintah dan Pemerintah Daerah wajib mengembangkan dan memanfaatkan kemajuan teknologi informasi untuk meningkatkan kemampuan mengelola keuangan daerah, dan mendistribusikan informasi keuangan daerah ke layanan publik.

Masih ditemukan penyimpangan dan kebocoran di dalam laporan keuangan oleh BPK, menunjukkan bahwa Laporan Keuangan Pemerintah Daerah belum memenuhi karakteristik atau nilai informasi yang disyaratkan. Hasil audit yang dilakukan oleh BPK, BPK memberikan opini "tidak wajar dan/atau disclaimer" diantaranya disebabkan oleh kelemahan sistem pengendalian intern yang dimiliki oleh pemerintah daerah terkait. Untuk menghasilkan laporan keuangan pemerintah daerah diperlukan proses dan tahap-tahap yang harus dilalui yang diatur dalam sistem akuntansi pemerintah daerah. Sistem Pengendalian Intern (SPI) berpengaruh terhadap transparansi dan akuntabilitas pengelolaan keuangan daerah (Sari et al., 2017)

Penelitian yang dilakukan Widari \& Sutrisno (2017) dan Purbasari \& Bawono (2017) membuktikan secara empiris bahwa sistem pengendalian internal pemerintah daerah berpengaruh terhadap akuntabilitas laporan keuangan pemerintah daerah.

$\mathrm{H}_{1}$ : $z$ berpengaruh positif terhdap akuntabilitas laporan keuangan daerah.

Dalam pengelolaan keuangan daerah yang baik, OPD harus memiliki sumber daya manusia yang kompeten, yang didukung dengan latar belakang pendidikan akuntansi, sering mengikuti pendidikan dan pelatihan, dan mempunyai pengalaman di bidang keuangan. Hal tersebut diperlukan untuk menerapkan sistem akuntansi yang ada. Sumber Daya Manusia (SDM) yang kompeten tersebut akan mampu memahami logika akuntansi dengan baik. 
Kegagalan sumber daya manusia Pemerintah Daerah dalam memahami dan menerapkan logika akuntansi akan berdampak pada kekeliruan laporan keuangan yang dibuat dan ketidaksesuaian laporan dengan standar yang ditetapkan pemerintah. Sumber daya manusia merupakan satu-satunya sumber daya yang memiliki akal perasaan, keinginan, keterampilan, pengetahuan, dorongan, daya dan karya (rasio, rasa dan karsa). Kompetensi SDM berpengaruh terhadap akuntabilitas dari pelaporan keuangan akuntansi (Febri et al., 2019).

$\mathrm{H}_{2}$ : Kompetensi sumber daya manusia berpengaruh positif terhadap akuntabilitas laporan keuangan daerah.

Pengendalian intern terdiri atas kebijakan dan prosedur yang digunakan dalam mencapai sasaran dan menjamin atau menyediakan informasi keuangan yang andal, serta menjamin ditaatinya hukum dan peraturan yang berlaku. Sistem pengendalian intern diharapkan mampu mencegah dan mendeteksi terjadinya kesalahan dalam proses akuntansi serta dapat memberikan perlindungan bagi data organisasi dari adanya ancaman penyelewengan atau sabotase sistem.Hal ini diperkuat oleh penelitian (Alamsyah et al., 2017), yang menyatakan bahwa sistem pengendalian intern berpengaruh positif signifikan terhadap kualitas laporan keuangan daerah. Hasil penelitian ini menunjukkan semakin tinggi penerapan SPI, maka semakin tinggi pula pengaruhnya terhadap kualitas laporan keuangan. Sejalan dengan penelitian oleh Roshanti, Sujana, \& Sinarwati (2014), sistem pengendalian intern berpengaruh positif dan signifikan terhadap keterandalan pelaporan keuangan pemerintah daerah. Keuangan. Penelitian yang dilakukan oleh Altamuro, Hall, \& Beatty (2008) dengan judul improvements ofmonitoring and reporting on internalcontrol toimprove the quality of financial reporting on the banking industry. The importance of internal control over financial reporting in realizing the quality of financial reporting. Selanjutnya penelitian oleh Astuti (2015), sistem Pengendalian Intern mempunyai hubungan erat dan berpengaruh signifikan terhadap kualitas laporan keuangan pada Dinas Kota Bandung, artinya semakin baik Sistem Pengendalian Intern dalam Penerapan lingkungan pengendalian, penilaian resiko, kegiatan pengendalian, informasi dan kumunikasi, dan pemantauan, maka hal tersebut akan meningkatkan kualitas laporan keuangan. Susilawati \& Riana (2014) juga menyatakan bahwa sistem pengendaalian internal berpengaruh pisitif terhadap kualitas laporan keuangan.

Berdasarkan uraian tersebut, diduga terdapat hubungan positif antara sistem pengendalian internal dengan kualitas infotmasi laporan keuangan daerah, sehingga hubungan itu di hipotesiskan sebagai berikut.

$\mathrm{H}_{3}$ : Sistem pengendalian internal berpengaruh positih terhadap kualitas informasi laporan keuangan daerah.

Pendekatan kontijensi dalam penelitian ini akan digunakan untuk mengevaluasi hubungan antara kompetensi SDM dengan kualitas laporan keuangan. Berdasarkan pendekatan diatas, ada dugaan bahwaadanyahubungan antara kompetensi SDM dengan kualitas laporan keuangan. Widari \& Sutrisno, (2017) mengatakan dibutuhkan dukungan SDM yang kompeten dan profesional dalam pengelolaan keuangan. Penyiapan dan penyusunan laporan keuangan tersebut memerlukan SDM yangmenguasailaporan keuangan. Dengan demikian penulis dapat menyimpulkan bahwa Sumber daya yangkompeten adalah SDM 
yang dapat melakukan sebuahtugas dengan kinerja yang efektif dan efisien untuk mencapai tujuan. Sehingga dalam hal ini yang menjadi indikator untuk mengukur kompetensi sumber dayamanusia, yaitu Latar Belakang Pendidikan, Pengetahuan, Keterampilan, dan Sikap.

$\mathrm{H}_{4}$ : Kompetensi sumber daya manusia berpengaruh positif terhadap kualitas informasi laporan keuangan daerah.

Karakteristik kualitatif laporan keuangan adalah ukuran-ukuran normatif yang perlu diwujudkan dalam informasi akuntansi sehingga dapat memenuhi tujuannya. Keempat karakteristik berikut ini merupakan prasyarat normatif yang diperlukan agar laporan keuangan pemerintah dapat memenuhi kualitas yang dikehendaki: relevan, andal, dapat dibandingkan, dan dapat dipahami.

$\mathrm{H}_{5}$ : Kualitas informasi laporan keuangan daerah berpengaruh positif terhadap akuntabilitas laporan keuangan daerah.

Standar Akuntansi Pemerintahan (SAP) dalam pengungkapan kebijakan akuntansi yang diterapkan akan membantu pembaca untuk dapat menghindari kesalahpahaman dalam membaca laporan keuangan. Pengungkapan kebijakan akuntansi dalam laporan keuangan dimaksudkan agar laporan keuangan dapat dimengerti. Pengungkapan kebijakan tersebut merupakan bagian yang tidak terpisahkan dari laporan keuangan yang sangat membantu pemakai laporan keuangan, karena kadang kadang perlakuan yang tidak tepat atau salah digunakan untuk suatu komponen laporan realisasi anggaran, neraca, laporan arus kas, atau laporan lainnya yang merupakan pengungkapan kebijakan akuntansi terpilih. Selain itu penetapan kebijakan akuntansi terpilih dimaksudkan untuk menjamin adanya keseragaman pencatatan dalam setiap transaksi akuntansi di setiap satuan kerja. (Hafzan, 2017) menyatakan bahwa kualitas keuangan dapat diukur berdasarkan karakteristik diantaranya: (1) dapat dipahami, (2) relevan, (3) materialitas, (4) keandalan/reliabilitas, (5) penyajian jujur, (6) substansi mengungguli bentuk, (7) netralitas, (8) pertimbangan sehat, (9) kelengkapan, dan (10) dapat dibandingkan. Untuk menyusun laporan keuangan yang berkualitas maka penggunaan sistem informasi manajemen sangat diperlukan untuk mengurangi ketidaktelitian dan tingkat kesalahan dalam penyusunan laporan.Salah satu misi dalam penerapan Sistem Informasi Manajemen Daerah ialah meningkatkan kinerja pengelola keuangan di tiap-tiap Operasi Perangkat Daerah dan menerapkan tata kelola pemerintahan yang baik dan bersih, bebas dari segala tindakan yang menjurus ke arah kolusi korupsi dan nepotisme. Dalam pernyataan diatas dapat dilihat bahwa sistem pengendalian internal yang baik, kompetensi sumber daya manusia yang berkualitas dan memadai tentu akan menghasilkan kualitas informasi laporan keuangan yang relevan, andal, dapat dibandingkan dan dapat dipahami, jika kualitas informasi laporan keuangan daerah sudah memenuhi kriteria tersebut maka akan terciptanya akuntabilitas laporan keuangan daerah.

$\mathrm{H}_{6}$ : Kualitas informasi laporan keuangan daerah memediasi pengaruh sistem pengendalian internal dan kompetensi sumber daya manusia dengan Akuntabilitas laporan keuangan daerah. 


\section{METODE PENELITIAN}

Penelitian ini dilakukan pada 29 Organisasi Perangkat Daerah Kabupaten Badung. Pemilihan lokasi tersebut karena berdasarkan Badan Pengelola Keuangan dan Aset Daerah Provinsi Bali Tahun 2015-2017, menunjukkan daerah dengan anggaran dan realisasi nominal pendapatan tertinggi dalam Anggaran Pendapatan Daerah Provinsi Bali. Populasi dalam penelitian ini adalah kepala dan staf sub bidang akuntansi atau penatausahaan keuangan disetiap OPD yang berada di pusat pemerintahan Kabupaten Badung. Teknik penentuan sampel dalam penelitian ini adalah dengan menggunakan metode non probabilty sampling dengan teknik sampling jenuh, artinya semua populasi dijadikan sampel. Jadi kepala dan staf sub bidang akuntansi atau penatausahaan keuangan disetiap OPD yang berada di pusat pemerintahan Kabupaten Badung merupakan sampel dari penelitian ini.

Teknik analisis data yang digunakan dalam penelitian ini adalah teknik analisis jalur (path analysis). Koefisien jalur dihitung dengan dua persamaan struktural yaitu:

$\mathrm{Z}=\alpha+p_{3} X_{1}+p_{3} X_{2}+\varepsilon_{1}$

$\mathrm{Y}=\alpha+p_{2} \mathrm{Z}+p_{1} X_{1}+p_{1} X_{2}+\varepsilon_{2}$

Keterangan

Y

$\mathrm{Z}$

: variabel akuntabilitas laporan keuangan daerah

$X_{1}$

$X_{2} \quad$ : variabel kompetensi sumber daya manusia

: variabel mediasi kualitas informasi laporan keuangan daerah

$p_{1}, p_{2}, p_{3} \quad$ : koefisien regresi untuk masing-masing variabel $X_{1}, X_{2}, Z$

$\varepsilon_{1}, \varepsilon_{2} \quad$ : nilai kekeliruan taksiran standar

Pengujian hipotesis mediasi dapat dilakukan dengan prosedur yang di kembangkan oleh Sobel (1982) dan dikenal dengan Uji Sobel (Sobel Test). Standar error tidak langsung (indirect effect) $S_{a b}$ dihitung dengan rumus berikut ini.

$S_{a b}=b^{2} S_{a}^{2}+a^{2} S_{b}^{2}+S_{a}^{2} S_{b}^{2}$

Untuk menguji signifikansi pengaruh tidak langsung maka nilai z dari koefisien ab dihitung drngan rumus sebagai berikut:

$$
\mathrm{z}={ }^{a b} S_{a b}
$$

Indikator didalam analisis jalur, yaitu koefisien determinasi total. Koefisien dterminasi total merupakan total keragaman data dimana dirumuskan dengan persamaan berikut.

$$
R^{2} \mathrm{~m}=1-\left(\varepsilon_{1}\right)^{2}\left(\varepsilon_{2}\right)^{2}
$$

Keterangan:

$\begin{array}{ll}R^{2} \mathrm{~m} & : \text { koefisien determinasi total } \\ \varepsilon_{1}, \varepsilon_{2} & : \text { nilai kekeliruan taksiran standar }\end{array}$

\section{HASIL DAN PEMBAHASAN}

Perhitungan koefisien path dilakukan dengan analisis regresi melalui software SPSS 24.0 for Windows, diperoleh hasil yang ditunjukan pada Tabel 2.

Berdasarkan hasil analisis jalur model 1 seperti yang disajikan pada Tabel 2, maka dapat dibuat persamaan struktural sebagai berikut. 
$\mathrm{M}=0,540 \mathrm{X}_{1}+0,305 \mathrm{X}_{2}+0,115$

Tabel 2. Hasil Analisis Jalur Model 1

\begin{tabular}{llllll}
\hline & \multicolumn{2}{c}{$\begin{array}{c}\text { Unstandardized } \\
\text { Coefficients }\end{array}$} & $\begin{array}{c}\text { Standardized } \\
\text { Coefficients }\end{array}$ & \\
\cline { 2 - 4 } & $B$ & Std. Error & Beta & $t$ & Sig. \\
\hline $\begin{array}{l}\text { (Constant) } \\
\begin{array}{l}\text { Sistem pengendalian } \\
\text { internal }\end{array}\end{array}$ & $-0,750$ & 4,873 & & $-0,154$ & 0,878 \\
$\quad \begin{array}{l}\text { Kompetensi sumber daya } \\
\text { manusia }\end{array}$ & 0,643 & 0,119 & 0,540 & 5,388 & 0,000 \\
\hline
\end{tabular}

Sumber: Data Penelitian, 2019

Nilai koefisien regresi variabel sistem pengendalian internal dan Kompetensi sumber daya manusia bernilai positif dengan nilai signifikansi uji $t$ kurang dari 0,05. Hal ini menunjukkan bahwa variabel sistem pengendalian internal dan Kompetensi sumber daya manusia memiliki pengaruh positif yang signifikan terhadap variabel kualitas informasi. Besarnya pengaruh variabel bebas terhadap variabel terikat yang ditunjukkan oleh nilai determinasi total ( $R$ Square) sebesar 0,511 mempunyai arti bahwa sebesar $51,1 \%$ variasi kualitas informasi dipengaruhi oleh variasi sistem pengendalian internaldan Kompetensi sumber daya manusia, sedangkan sisanya sebesar $48,9 \%$ dijelaskan oleh faktor lain yang tidak dimasukkan ke dalam model.

Tabel 3. Hasil Analisis Jalur Model 2

\begin{tabular}{llllll}
\hline & \multicolumn{2}{c}{$\begin{array}{c}\text { Unstandardized } \\
\text { Coefficients }\end{array}$} & $\begin{array}{c}\text { Standardized } \\
\text { Coefficients }\end{array}$ & \\
\cline { 2 - 4 } Model & $B$ & Std. Error & Beta & T & Sig. \\
\hline $\begin{array}{llllll}\text { (Constant) } \\
\quad \begin{array}{l}\text { Sistem pengendalian } \\
\text { internal }\end{array}\end{array}$ & -3.085 & 2,183 & & $-1,413$ & 0,163 \\
$\quad \begin{array}{l}\text { Kompetensi sumber } \\
\text { daya manusia }\end{array}$ & 0,258 & 0,066 & 0,381 & 3,929 & 0,000 \\
$\quad$ Kualitas informasi & 0,191 & 0,055 & 0,296 & 3,475 & 0,001 \\
\hline
\end{tabular}

Sumber: Data Penelitian, 2019

Berdasarkan hasil analisis jalur model 2 seperti yang disajikan pada Tabel 3, maka dapat dibuat persamaan struktural sebagai berikut.

Tabel 4. Nilai Determinasi Total $\left(R^{2}\right)$

\begin{tabular}{llll}
\hline Model & $\mathrm{R}$ & $R$ Square & Adjusted R Square \\
\hline 1 & $0,838^{\mathrm{a}}$ & 0,702 & 0,686 \\
\hline
\end{tabular}

Sumber: Data Penelitian, 2019

Nilai koefisien regresi variabel sistem pengendalian internal, Kompetensi sumber daya manusia dan kualitas informasi bernilai positif dengan nilai signifikansi uji $t$ kurang dari 0,05. Hal ini menunjukkan bahwa variabel sistem pengendalian internal, Kompetensi sumber daya manusia dan kualitas informasi memiliki pengaruh positif yang signifikan terhadap variabel akuntabilitas keuangan daerah. Besarnya pengaruh variabel bebas terhadap variabel terikat yang ditunjukkan oleh nilai determinasi total ( $R$ Square) sebesar 0,702 mempunyai arti bahwa sebesar $70,2 \%$ variasi akuntabilitas keuangan daerah dipengaruhi oleh variasi sistem pengendalian internal, Kompetensi sumber daya 
manusia dan kualitas informasi, sedangkan sisanya sebesar 39,8\% dijelaskan oleh faktor lain yang tidak dimasukkan ke dalam model.

Nilai determinasi total sebesar 0,855 mempunyai arti bahwa sebesar $85,5 \%$ variasi akuntabilitas keuangan daerah dipengaruhi oleh variasi sistem pengendalian internal, Kompetensi sumber daya manusia dan kualitas informasi, sedangkan sisanya sebesar $14,5 \%$ djelaskan oleh faktor lain yang tidak dimasukkan ke dalam model. Perhitungan pengaruh antar variabel dirangkum dalam Tabel 5, sebagai berikut.

Tabel 5. Rangkuman Variabel Sistem Pengendalian Internal $\left(X_{1}\right)$ terhadap Akuntabilitas Keuangan Daerah (Y) dengan Kualitas Informasi (M)

\begin{tabular}{llll}
\hline Pengaruh Variabel & $\begin{array}{l}\text { Pengaruh } \\
\text { Langsung }\end{array}$ & $\begin{array}{l}\text { Pengaruh Tidak } \\
\text { Langsung }\end{array}$ & $\begin{array}{l}\text { Pengaruh } \\
\text { Total }\end{array}$ \\
\hline $\mathrm{X}_{1} \rightarrow \mathrm{M}$ & 0,540 & - & 0,540 \\
$\mathrm{X}_{1} \rightarrow \mathrm{Y}$ & 0,381 & 0,181 & 0,562 \\
$\mathrm{M} \rightarrow \mathrm{Y}$ & 0,336 & - & 0,336 \\
$\mathrm{X}_{2} \rightarrow \mathrm{M}$ & 0,305 & - & 0,305 \\
$\mathrm{X}_{2} \rightarrow \mathrm{Y}$ & 0,296 & 0,102 & 0,398 \\
$\mathrm{M} \rightarrow \mathrm{Y}$ & 0,336 & - & 0,336 \\
\hline
\end{tabular}

Sumber: Data Penelitian, 2019

Tabel 5, menunjukkan bahwa pengaruh langsung sistem pengendalian internal terhadap kualitas informasi adalah sebesar 0,540. Pengaruh langsung variabel sistem pengendalian internal terhadap akuntabilitas keuangan daerah sebesar 0,381. Pengaruh langsung variabel kualitas informasi terhadap akuntabilitas keuangan daerah sebesar 0,336. Hal ini berarti bahwa variabel akuntabilitas keuangan daerah lebih besar dipengaruhi sistem pengendalian internal dari pada kualitas informasi. Sedangkan pengaruh tidak langsung variabel sistem pengendalian internal terhadap akuntabilitas keuangan daerah melalui kualitas informasi sebesar 0,181. Jadi pengaruh total variabel sistem pengendalian internal terhadap akuntabilitas keuangan daerah melalui kualitas informasi adalah sebesar 0,562. Jadi dapat disimpulkan bahwa lebih besar total pengaruh sistem pengendalian internal terhadap akuntabilitas keuangan daerah yang melalui kualitas informasi, daripada pengaruh langsung sistem pengendalian internal terhadap akuntabilitas keuangan daerah tanpa melalui variable kualitas informasi.

Tabel 5, menunjukkan bahwa pengaruh langsung kompetensi sumber daya manusia terhadap kualitas informasi adalah sebesar 0,305. Pengaruh langsung variabel kompetensi sumber daya manusia terhadap akuntabilitas keuangan daerah sebesar 0,296. Pengaruh langsung variabel kualitas informasi terhadap akuntabilitas keuangan daerah sebesar 0,336. Hal ini berarti bahwa variabel akuntabilitas keuangan daerah lebih besar dipengaruhi kompetensi sumber daya manusia dari pada kualitas informasi. Sedangkan pengaruh tidak langsung variabel Kompetensi sumber daya manusia terhadap akuntabilitas keuangan daerah melalui kualitas informasi sebesar 0,105. Jadi pengaruh total variabel kompetensi sumber daya manusia terhadap akuntabilitas keuangan daerah melalui kualitas informasi adalah sebesar 0,398. Jadi dapat disimpulkan bahwa lebih besar total pengaruh kompetensi sumber daya manusia terhadap akuntabilitas keuangan daerah yang melalui kualitas informasi, daripada 
pengaruh langsung kompetensi sumber daya manusia terhadap akuntabilitas keuangan daerah tanpa melalui variable kualitas informasi.

Berdasarkan hasil analisis pengaruh sistem pengendalian internal terhadap akuntabilitas keuangan daerah diperoleh nilai Signifikansi sebesar 0,000 dengan nilai koefisien beta 0,258 bernilai positif. Nilai Signifikansi 0,000 < 0,05 mengindikasikan bahwa $\mathrm{H}_{0}$ ditolak dan $\mathrm{H}_{3}$ diterima. Hasil ini mempunyai arti bahwa sistem pengendalian internal berpengaruh positif dan signifikan terhadap akuntabilitas keuangan daerah. Hal tersebut berarti bahwa jika sistem pengendalian internal semakin baik maka akuntabilitas keuangan daerah akan semakin baik, begitupula sebaliknya jika system pengendali internal semakin buruk maka akuntabilitas keuangan daerah semakin buruk. Masih ditemukan penyimpangan dan kebocoran di dalam laporan keuangan oleh BPK, menunjukkan bahwa Laporan Keuangan Pemerintah Daerah belum memenuhi karakteristik atau nilai informasi yang disyaratkan. Hasil audit yang dilakukan oleh BPK, BPK memberikan opini "tidak wajar dan/atau disclaimer" diantaranya disebabkan oleh kelemahan sistem pengendalian intern yang dimiliki oleh pemerintah daerah terkait. Untuk menghasilkan laporan keuangan pemerintah daerah diperlukan proses dan tahap-tahap yang harus dilalui yang diatur dalam sistem akuntansi pemerintah daerah. Sistem Pengendalian Intern (SPI) berpengaruh terhadap transparansi dan akuntabilitas pengelolaan keuangan daerah (Sari et al., 2017) Penelitian yang dilakukan Widari \& Sutrisno (2017) dan Purbasari \& Bawono (2017) membuktikan secara empiris bahwa sistem pengendalian internal pemerintah daerah berpengaruh terhadap akuntabilitas laporan keuangan pemerintah daerah.

Berdasarkan hasil analisis pengaruh kompetensi sumber daya manusia terhadap akuntabilitas keuangan daerah diperoleh nilai Signifikansi sebesar 0,001 dengan nilai koefisien beta 0,296 bernilai positif. Nilai Signifikansi 0,001< 0,05 mengindikasikan bahwa $\mathrm{H}_{0}$ ditolak dan $\mathrm{H}_{4}$ diterima. Hasil ini mempunyai arti bahwa kompetensi sumber daya manusia berpengaruh positif dan signifikan terhadap akuntabilitas keuangan daerah. Hal tersebut berarti bahwa jika kompetensi sumber daya manusia semakin baik maka akuntabilitas keuangan daerah akan semakin baik, begitupula sebaliknya jika kompetensi sumber daya manusia semakin buruk maka akuntabilitas keuangan daerah semakin buruk. Dalam pengelolaan keuangan daerah yang baik, OPD harus memiliki sumber daya manusia yang kompeten, yang didukung dengan latar belakang pendidikan akuntansi, sering mengikuti pendidikan dan pelatihan, dan mempunyai pengalaman di bidang keuangan. Hal tersebut diperlukan untuk menerapkan sistem akuntansi yang ada. SDM yang kompeten tersebut akan mampu memahami logika akuntansi dengan baik. Kegagalan sumber daya manusia Pemerintah Daerah dalam memahami dan menerapkan logika akuntansi akan berdampak pada kekeliruan laporan keuangan yang dibuat dan ketidaksesuaian laporan dengan standar yang ditetapkan pemerintah. Sumber daya manusia merupakan satu-satunya sumber daya yang memiliki akal perasaan, keinginan, keterampilan, pengetahuan, dorongan, daya dan karya (rasio, rasa dan karsa). Kompetensi SDM berpengaruh terhadap akuntabilitas dari pelaporan keuangan akuntansi (Febri et al., 2019). 
Berdasarkan hasil analisis pengaruh sistem pengendalian internal terhadap kualitas informasi diperoleh nilai Signifikansi sebesar 0,000 dengan nilai koefisien beta 0,540 bernilai positif. Nilai Signifikansi 0,000 $<0,05$ mengindikasikan bahwa $\mathrm{H}_{0}$ ditolak dan $\mathrm{H}_{1}$ diterima. Hasil ini mempunyai arti bahwa sistem pengendalian internal berpengaruh positif dan signifikan terhadap kualitas Informasi. Hal ini berarti bahwa jika system pengendalian internal semakin baik maka kualitas informasi akan semakin baik, begipula sebaliknya jika system pengendalian internal semakin buruk maka kualitas informasi juga akan semakin buruk. Pengendalian intern terdiri atas kebijakan dan prosedur yang digunakan dalam mencapai sasaran dan menjamin atau menyediakan informasi keuangan yang andal, serta menjamin ditaatinya hukum dan peraturan yang berlaku. Sistem pengendalian intern diharapkan mampu mencegah dan mendeteksi terjadinya kesalahan dalam proses akuntansi serta dapat memberikan perlindungan bagi data organisasi dari adanya ancaman penyelewengan atau sabotase sistem.Hal ini diperkuat oleh penelitian (Alamsyah et al., 2017), yang menyatakan bahwa sistem pengendalian intern berpengaruh positif signifikan terhadap kualitas laporan keuangan daerah. Hasil penelitian ini menunjukkan semakin tinggi penerapan SPI, maka semakin tinggi pula pengaruhnya terhadap kualitas laporan keuangan. Sejalan dengan penelitian oleh Roshanti, Sujana, \& Sinarwati (2014), sistem pengendalian intern berpengaruh positif dan signifikan terhadap keterandalan pelaporan keuangan pemerintah daerah. Keuangan. Penelitian yang dilakukan oleh Altamuro, Hall, \& Beatty (2008) dengan judul improvements ofmonitoring and reporting on internalcontrol toimprove the quality of financial reporting on the banking industry. The importance of internal control over financial reporting in realizing the quality of financial reporting. Selanjutnya penelitian oleh Astuti (2015), sistem Pengendalian Intern mempunyai hubungan erat dan berpengaruh signifikan terhadap kualitas laporan keuangan pada Dinas Kota Bandung, artinya semakin baik Sistem Pengendalian Intern dalam Penerapan lingkungan pengendalian, penilaian resiko, kegiatan pengendalian, informasi dan kumunikasi, dan pemantauan, maka hal tersebut akan meningkatkan kualitas laporan keuangan. Susilawati \& Riana (2014) juga menyatakan bahwa sistem pengendaalian internal berpengaruh pisitif terhadap kualitas laporan keuangan.

Berdasarkan hasil analisis pengaruh kompetensi sumber daya manusia terhadap kualitas informasi diperoleh nilai Signifikansi sebesar 0,004 dengan nilai koefisien beta 0,305 bernilai positif. Nilai Signifikansi 0,004 $<0,05$ mengindikasikan bahwa $\mathrm{H}_{0}$ ditolak dan $\mathrm{H}_{2}$ diterima. Hasil ini mempunyai arti bahwa kompetensi sumber daya manusia berpengaruh positif dan signifikan terhadap kualitas Informasi. Hal tersebut berarti bahwa jika kompetensi sumber daya manusia semakin baik maka kualitas informasi akan semakin baik, begitupula sebaliknya jika kompetensi sumber daya manusia semakin buruk maka kualitas informasi semakin buruk. Pendekatan kontijensi dalam penelitian ini akan digunakan untuk mengevaluasi hubungan antara kompetensi SDM dengan kualitas laporan keuangan. Berdasarkan pendekatan diatas, ada dugaan bahwa adanya hubungan antara kompetensi SDM dengan kualitas laporan keuangan. Widari \& Sutrisno, (2017) mengatakan dibutuhkan dukungan SDM yang kompeten dan profesional dalam pengelolaan keuangan. Penyiapan dan 
penyusunan laporan keuangan tersebut memerlukan SDM yangmenguasailaporan keuangan. Dengan demikian penulis dapat menyimpulkan bahwa Sumber daya yang kompeten adalah sumber daya manusia yang dapat melakukan sebuahtugas dengan kinerja yang efektif dan efisien untuk mencapai tujuan. Sehingga dalam hal ini yang menjadi indikator untuk mengukur kompetensi sumberdaya manusia, yaitu Latar Belakang Pendidikan, Pengetahuan, Keterampilan, dan Sikap.

Berdasarkan hasil analisis pengaruh kualitas informasi terhadap akuntabilitas keuangan daerah diperoleh nilai Signifikansi sebesar 0,002 dengan nilai koefisien beta 0,336 bernilai positif. Nilai Signifikansi 0,002 $<0,05$ mengindikasikan bahwa $\mathrm{H}_{0}$ ditolak dan $\mathrm{H}_{5}$ diterima. Hasil ini mempunyai arti bahwa kualitas informasi berpengaruh positif dan signifikan terhadap akuntabilitas keuangan daerah. Hal tersebut berarti bahwa jika kualitas informasi semakin baik maka akuntabilitas keuangan daerah akan semakin baik, begitupula sebaliknya jika kualitas informasi semakin buruk maka akuntabilitas keuangan daerah semakin buruk. Karakteristik kualitatif laporan keuangan adalah ukuran-ukuran normatif yang perlu diwujudkan dalam informasi akuntansi sehingga dapat memenuhi tujuannya. Keempat karakteristik berikut ini merupakan prasyarat normatif yang diperlukan agar laporan keuangan pemerintah dapat memenuhi kualitas yang dikehendaki: relevan, andal, dapat dibandingkan, dan dapat dipahami.

Berdasarkan hasil analisis hubungan kualitas informasi laporan keuangan daerah memediasi sistem pengendalian internal dengan akuntabilitas laporan keuangan daerah diperoleh $t$ hitung sebesar 3,59 $>1,96$. Artinya kualitas informasi mampu memediasi pengaruh sistem pengendalian internal terhadap akuntabilitas keuangan daerah. Hal ini berarti bahwa jika kualitas informasi semakin baik maka pengaruh sistem pengendalian internal terhadap akuntabilitas keuangan daerah akan semakin baik, begitupula sebaliknya jika kulaitas informasi semakin buruk maka pengaruh sistem pengendalian interal terhadap akuntabilitas keuangan daerah akan semakin buruk pula.

Berdasarkan hasil analisis hubungan kualitas informasi laporan keuangan daerah memediasi sumber daya manusia dengan akuntabilitas laporan keuangan daerah diperoleh $t$ hitung sebesar 2,374 $>1$,96. Artinya kualitas informasi mampu memediasi pengaruh kompetensi sumber daya manusia terhadap akuntabilitas keuangan daerah. Hal ini berarti bahwa jika kualitas informasi semakin baik maka pengaruh sumber daya manusia terhadap akuntabilitas keuangan daerah akan semakin baik, begitupula sebaliknya jika kulaitas informasi semakin buruk maka pengaruh sumber daya manusia terhadap akuntabilitas keuangan daerah akan semakin buruk pula.

\section{SIMPULAN}

Berdasarkan pemaparan dapat dinyatakan bahwa system pengendalian internal secara signifikan berpengaruh positif dengan kualitas informasi. Hasil tersebut mengimplikasikan bahwa agar kualitas informasi meningkat maka pihak manajemen perusahaan hendaknya meningkatkan system pengendalian internal yang sesuai dengan aturan perusahaan serta keuntungan yang diperoleh 
perusahaan. Selain itu, pihak manajemen hendaknya memberikan perhatian yang serius dengan begitu system pengendalian internal akan meningkat.

Kompetensi sumber daya manusia secara signifikan berpengaruh positif dengan kualitas informasi. Hal tersebut berimplikasi bahawa untuk meningkatkan kualitas informasi pihak manajemen perusahaan hendaknya meningkatkan seleksi dalam pemelihan pegawai a yang berlaku sesuai dengan undang - undang ketenaga kerjaan. Selain itu, pihak manajemen perusahaan hendaknya tidak memberikan tanggung jawab yang tidak sesuai dengan jabatan serta deskripsi pekerjaan yang diemban karyawan.

Sistem pengendalian secara signifikan juga berpengaruh positif dengan akuntabilitas keuangan daerah. Hasil tersebut mengimplikasikan bahwa pihak manajemen hendaknya mengkondisikan system pengendalian internal agar akuntabilitas keuangan daerah tetap terjaga dengan baik. Hal tersebut dilakukan dengan memperhatikan setiap kinerrja agar dapat berjalan sesuai aturan sehingga proses pengendalian dapat dilakukan dengan baik.

Kompetensi sumber daya manusia secara signifikan berpengaruh positif dengan akuntabilitas keuangan daerah. Hasil tersebut mengimplikasikan bahwa pihak manajemen hendaknya mengkondisikan kompetensi sumber daya manusia agar akuntabilitas keuangan daerah baik. Hal tersebut dapat dilakukan dengan cara dalam pemilihan pegawai dilakukan dengan ketat serta memperhatikan kompetensinya agar diperoleh pegawai sesuai dengan kebutuhan perusahaan.

Selain itu, kualitas informasi secara signifikan berpengaruh positif dengan akuntabilitas keuangan daerah. Hasil tersebut mengimplikasikan bahwa pihak manajemen hendaknya mengkondisikan kualitas informasi agar akuntabilitas keuangan daerah baik. Hal tersebut dapat dilakukan dengan cara memberikan pelayanan yang baik dalam hal komunikasi antar sesama pegawai. Dengan hal tersebut pegawai diberikan edukasi dalam hal penyampaian hal dengan baik dan benar. Sehingga kualitas informasi yang diberikan sesuai dengan kebutuhan.

\section{REFERENSI}

Alamsyah, M. R., Rahayu, S., \& Muslih, M. (2017). Kompetensi Sumber Daya Manusia, Penerapan Sistem Akuntansi Keuangan Daerah (Sakd), Pemanfaatan Teknologi Informasi, Dan Sistem Pengendalian Internal Terhadap Kualitas Laporan Keuangan Daerah (Studi Empiris Pada Satuan Kineja Perangkat Daerah (Skpd) Kota D. Majalah Ilmiah UNIKOM, 15(2). https:// doi.org/10.34010/miu.v15i2.559

Altamuro, J., Hall, F., \& Beatty, A. L. (2008). How Does Internal Control Regulation Affect Financial Reporting? How Does Internal Control Regulation Affect Financial Reporting? Journal of Accounting and Economics, 49(1), 58-74.

Astuti, T. P. dan Y. (2015). Good Governance Pengelolaan Keuangan Desa Menyongsong Berlakunya Undang-Undang Nomor .6 Tahun 2014. Universitas Setia Budi Surakarta., 1(6), 1-14.

Febri, D., Rahayu, S., \& Wiralestari. (2019). Competence , And Control Systems Government Interns To The. Thesis, 38-52. 
Hafzan, F. (2017). Pengaruh Kualitas Laporan Keuangan, Penyajian Laporan Keuangan Dan Aksesibilitas Laporan Keuangan Terhadap Akuntabilitas Pengelolaan Keuangan Daerah. 4(1).

J. Kim, T. Et al. 2016. On Maximizing Quality Of Information For The Internet Of Things: A Real-Time Scheduling Perspective (Invited Paper). IEEE 22nd International Conference On Embedded And Real-Time Computing Systems And Applications (RTCSA). 202-211.

Purbasari, H., \& Bawono, A. D. B. (2017). Pengaruh Desentralisasi Fiskal, Sistem Pengendalian Internal Dan Kinerja Pemerintah Daerah Terhadap Akuntabilitas Laporan Keuangan. Riset Akuntansi Dan Keuangan Indonesia, 2(2), 102-108. https://doi.org/10.23917/reaksi.v2i2.4884

Roshanti, A., Sujana, E., \& Sinarwati, K. (2014). Pengendalian Intern Terhadap Nilai Informasi Pelaporan. E-Journal S1 Ak Universitas Pendidikan Ganesha, 2(1).

Sari, E., Azlina, N., \& Julita. (2017). Pengaruh Sistem Pengendalian Intern, Penyajian Laporan Keuangan, Aksesibilitas Laporan Keuangan Dan Gaya Kepemimpinan Terhadap Transparansi Dan Akuntabilitas Pengelolaan Keuangan Daerah Di Kabupaten Indragiri Hulu. Jurnal Online Mahasiswa Fakultas Ekonomi Universitas Riau, 4(1), 571-585.

Susilawati, S., \& Riana, D. S. (2014). Standar Akuntansi Pemerintahan dan Sistem Pengendalian Intern Sebagai Anteseden Kualitas Laporan Keuangan Pemerintah Daerah. STAR - Study \& Accounting Research, 11(1), 15-32.

Suwardjono. (2005). Teori Akuntansi: Perekayasaan Pelaporan Keuangan (ketiga). Yogyakarta: BPFE.

Wahyono. (2004). Pengertian Sistem, Analisis dan Desai nSistem Informasi (Andi, Ed.). Yogyakarta.

Widari, L., \& Sutrisno. (2017). Pengaruh Sistem Pengendalian Internal Pemerintah dan Komitmen Organisasi Terhadap Kualitas Laporan Keuangan Daerah. Jurnal Ilmiah Ilmu Ekonomi, 5(10), 117-126. 